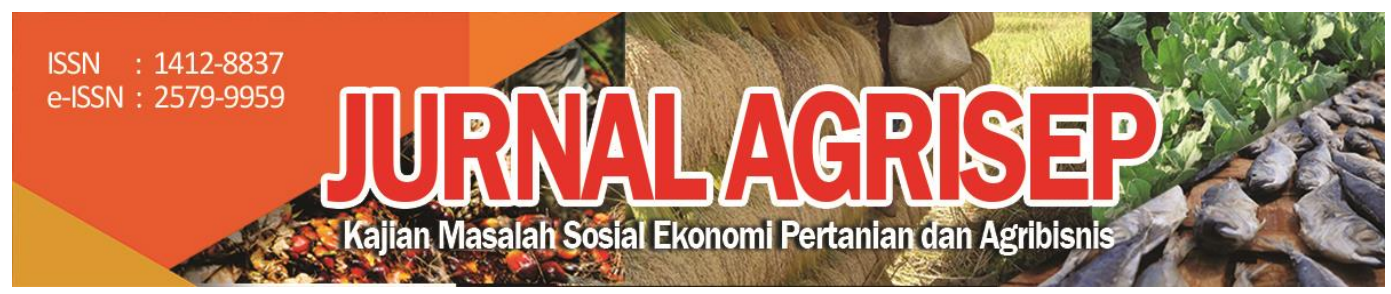

DOI: $10.31186 /$ jagrisep.19.2.361-374

\title{
DINAMIKA RANTAI PASOK BERAS DI KECAMATAN BANSARI KABUPATEN TEMANGGUNG
}

\section{The Dynamic of Rice Supply Chain in Bansari District Temanggung}

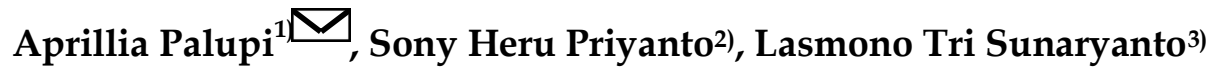 \\ 1),2),3) Program Studi Agribisnis. Fakultas Pertanian dan Bisnis. Universitas \\ Kristen Satya Wacana \\ Email: aprilliapalupi.ap@gmail.com
}

\begin{abstract}
Temanggung Regency is the rice producer with the third highest productivity in the province of Central Java. Bansari District, one of the sub-districts in Temanggung Regency, has the potential to be developed as an agricultural area because most of its people are farmer. The study of rice supply chain in Bansari sub-district Temanggung regency is significance in order to design the efficiency of rice supply chain mechanism in the interest of rice farmers' welfare in Bansari district Temanggung. The purpose of this research is to examine and review the patterns or mechanisms of rice supply chain and to analyse the role undertaken by the supply chain actors in Bansari district. The research method used a qualitative method. Data were collected through observation, interviews, documentation and library studies. The observed units in this research were the rice supply chain agents in Bansari subdistrict, namely rice farmers, rice milling entrepreneurs, rice traders and buyers or consumers of rice. The pattern of the rice supply chain actors in Bansari subdistrict, had only one supply chain flow, namely, the flow of products. There were several actors involved in the rice supply chain including farmers, active and passive traders, piners, milling, consumer households. The supply chain actors had their respective role in distributing rice from farmers to household consumers through the their relevant activities. There is no government intervention in supply chain in Bansari district. Business partnerships were required to develop businesses in the field of rice farming in Bansari district.
\end{abstract}

Keywords: Pattern and Mechanisms, Rice, Supply chain 


\section{ABSTRAK}

Kabupaten Temanggung merupakan penghasil beras dengan produktivitas tertinggi ketiga di Provinsi Jawa Tengah. Kecamatan Bansari merupakan salah satu wilayah di Kabupaten Temanggung yang mempunyai potensi sebagai daerah pertanian yang sebagian besar masyarakatnya adalah petani. Adanya studi mengenai rantai pasok beras di Kecamatan Bansari Kabupaten Temanggung merupakan suatu hal penting untuk merancang efisiensi mekanisme rantai pasok beras yang menguntungkan bagi petani beras di Kecamatan Bansari Kabupaten temanggung. Tujuan dari penelitian ini adalah untuk mengetahui dan mengkaji pola atau mekanisme rantai pasok beras serta mendiskripsikan peranan yang dilakukan oleh pelaku rantai pasok di Kecamatan Bansari. Metode penelitian yang dilaksanakan menggunakan metode diskriptif kualitatif dengan tehnik pengumpulan data melalui metode observasi, wawancara, dokumentasi dan studi pustaka. Unit amatan dalam penelitian ini adalah pelaku rantai pasok beras di Kecamatan Bansari yaitu petani padi, pelaku atau pengusaha penggilingan padi, pedagang beras dan pembeli atau konsumen beras. Pola mekanisme pelaku rantai pasok beras yang ada di Kecamatan Bansari, hanya memiliki satu aliran rantai pasok yaitu aliran produk. Terdapat beberapa pelaku yang terlibat dalam rantai pasok beras diantaranya petani, pedagang aktif dan pedagang pasif, pengepul, penebas, penggilingan, konsumen rumah tangga. Pelaku rantai pasok ini memiliki peran masing-masing dalam mendistribusikan beras dari petani hingga konsumen rumah tangga melalui aktifitas yang dilakukannya.Tidak ada campur tangan pemerintah dalam rantai pasok di Kecamatan Bansari. Diperlukan kemitraan bisnis untuk mengembangkan usaha di bidang usaha tani beras di Kecamatan Bansari.

Kata kunci: Beras, Pola dan Mekanisme, Rantai pasok

\section{PENDAHULUAN}

Dalam tatanan kehidupan bernegara di Indonesia, beras merupakan salah satu komoditas pertanian dan pangan yang memiliki nilai yang sangat penting dari banyak segi. Salah satu nilai penting tersebut, beras merupakan sumber pangan utama dan komoditas pertanian yang strategis. Beras memiliki nilai penting sebagai sumber pangan utama dikarenakan beras merupakan sumber pangan pokok sebagian besar masyarakat Indonesia, sekitar $90 \%$ penduduk Indonesia mengkonsumsi beras (Kusumaningrum, et.al. 2010). Bahkan konsumsi beras pada masyarakat Indonesia merupakan tertinggi di dunia setelah China dan India (Yanuarti dan Afsari, 2016). Sedangkan nilai penting beras sebagai komoditas pertanian yang strategis dikarenakan beras merupakan komoditas yang menjadi andalan bagi ketahanan pangan (Suryana dan Mardianto, 2001).

Dalam upaya meningkatkan ketahanan pangan nasional, stabilitas ketersediaan pasokan beras menjadi salah satu unsur penting yang harus terpenuhi. Untuk menjaga stabilitas ketersediaan pasokan beras dan memenuhi 
kebutuhan pangan, pemerintah berupaya menyediakan beras bagi seluruh masyarakat, memastikan pasokan beras harus selalu tersedia dalam jumlah yang aman, dan mengatur harga gabah yang layak ditingkat petani. Upaya tersebut dibuktikan pada tahun 2017 di tingkat internasional Indonesia merupakan salah satu produsen beras terbesar di dunia (https://www.indexmundi.com). Namun, tingginya produksi beras Indonesia ternyata diikuti pula dengan tingginya konsumsi beras. Indonesia menempati urutan ke-3 tertinggi didunia dalam konsumsi beras (https://www.statista.com). Hal ini berdampak pada tingginya kebutuhan beras untuk dikonsumsi, sehingga menuntut penyediaan beras yang lebih banyak.

Pada aktivitas produksi hingga konsumsi beras, banyak hal terjadi yang selalu menarik perhatian untuk menjadi sebuah penelitian. Salah satu hal menarik tersebut adalah mengenai dinamika rantai pasok beras. Pengertian dinamika rantai pasok menurut Pujawan dan Mahendrawati (2010) adalah gerakan jaringan perusahaan yang secara bersama-sama bekerja untuk menciptakan dan menghantarkan suatu produk ke tangan pemakai akhir. Pada rantai pasok beras ini berarti ada aktivitas memproduksi beras dan menghantarkan beras hingga ke konsumen akhir.

Dalam penelitiannya, Suoth, et.al. (2017) mengenai Analisis Desain Jaringan Supply Chain komoditas beras di Desa Karondoran Kecamatan Langowan timur Kabupaten Minahasa, hasil penelitian yang dilakukan membuktikan petani sebaiknya membuat alternatif desain jaringan yang lebih efektif dan efisien. Desain jaringan rantai pasok yang dilakukan, petani dapat memfungsikan koperasi atau kelompok tani sebagai sarana untuk mensejahterakan petani. Analisis desain jaringan rantai pasok lainnya dilakukan dengan menghilangkan pedagang besar, sehingga petani dapat langsung menjual beras ke konsumen atau pengecer tanpa melalui pedagang besar atau pengepul.

Sebagai kabupaten dengan dengan produktivitas penghasil beras tertinggi ketiga di Provinsi Jawa Tengah menurut data BPS tahun 2018, Temanggung merupakan daerah penghasil beras (https://jateng.bps.go.id). Kecamatan Bansari merupakan salah satu wilayah di Kabupaten Temanggung yang mempunyai potensi sebagai daerah pertanian yang sebagian besar masyarakatnya adalah petani. Belum adanya studi mengenai rantai pasok beras di Kecamatan Bansari Kabupaten Temanggung, kajian ini akan menarik dan signifikan untuk dilakukan.

Berdasarkan uraian diatas maka tujuan dari penelitian ini adalah untuk mengetahui dan mengkaji pola atau mekanisme rantai pasok beras di Kecamatan Bansari Kabupaten Temanggung dan mendiskripsikan peranan yang dilakukan oleh pelaku rantai pasok beras di Kecamatan Bansari Kabupaten Temanggung. 


\section{METODE PENELITIAN}

Unit analisis dalam penelitian ini adalah perorangan sebagai pelaku dinamika rantai pasok beras di Kecamatan Bansari. Penetapan unit analisis ini didasarkan pada aktivitas yang dilakukan pada rantai pasok beras di Kecamatan Bansari Kabupaten Temanggung sebagai pelaku rantai pasok. Sedangkan unit amatan dalam penelitian ini adalah pelaku rantai pasok beras di Kecamatan bansari yaitu petani padi, pelaku atau pengusaha penggilingan padi, pedagang beras dan pembeli atau konsumen beras.

Untuk memperoleh data kualitatif yang diinginkan maka dalam penelitian ini dilakukan pengambilan data primer dan data sekunder seperti yang dilakukan Sugiyono (2008) dengan tehnik pengumpulan data melalui metode observasi, wawancara, dokumentasi dan studi pustaka. Data primer dikumpulkan dari pelaku yang terlibat dalam rantai pasok yaitu petani, penggilingan, pedagang dan pembeli beras. Data sekunder dikumpulkan dari dokumentasi dan studi pustaka. Dokumentasi dilakukan dengan cara mengumpulkan data dengan mempelajari dan mencatat bagian-bagian yang dianggap penting yang terdapat baik di lokasi penelitian maupun di instansi yang ada hubungannya dengan lokasi penelitian. Studi pustaka yaitu studi literatur tentang konsep rantai pasok, hasil penelitian terdahulu, dan data-data terdokumentasi lainnya yang berkaitan dengan rantai pasok beras.

Dalam rangka menjawab permasalahan penelitian, maka analisis data dalam penelitian ini dilakukan secara diskriptif kualitatif. Hasil pengumpulan data tersebut kemudian disajikan dalam bentuk content analisis dengan penjelasan-penjelasan, selanjutnya diberi kesimpulan, sehingga dapat menjawab rumusan masalah, menjelaskan dan terfokus pada representasi terhadap fenomena yang hadir dalam penelitian.

Pada penelitian ini tehnik analisis data yang dilakukan adalah

1. Analisis pola atau mekanisme rantai pasok beras dilakukan dengan tehnik analisis deskriptif kualitatif. Analisis ini dilakukan untuk menganalisis model skema atau aliran rantai pasok beras. Analisis ini dilakukan dengan menunjukkan pola aliran rantai pasok yang terdiri dari aliran komoditas, aliran finansial dan aliran informasi.

2. Analisis peranan pelaku rantai pasok beras dilakukan dengan cara analisis diskriptif kualitatif yaitu menguraikan peranan setiap unsur dari rantai pasok beras serta aktivitas yang dilakukan pada setiap unsur rantai pasok.

Rincian prosedur dan pengolahan data bisa dilihat pada Tabel 1. 
Tabel 1. Prosedur dan Pengolahan Data Pola Rantai Pasok dan Peranan Pelaku Rantai Pasok

\begin{tabular}{|c|c|c|c|c|}
\hline $\begin{array}{c}\text { Kebutuhan } \\
\text { data }\end{array}$ & $\begin{array}{l}\text { Jenis } \\
\text { data }\end{array}$ & $\begin{array}{c}\text { Metode } \\
\text { pengumpulan } \\
\text { data }\end{array}$ & Alat analisis & Sumber data \\
\hline $\begin{array}{l}\text { Mengetahui } \\
\text { pola rantai } \\
\text { pasok beras di } \\
\text { Kecamatan } \\
\text { Bansari }\end{array}$ & Primer & Wawancara & $\begin{array}{l}\text { Pertanyaan untuk } \\
\text { mendapatkan data } \\
\text { yang digunakan } \\
\text { untuk membuat } \\
\text { pola rantai pasok }\end{array}$ & $\begin{array}{l}\text { Petani, } \\
\text { penggilingan, } \\
\text { pedagang dan } \\
\text { pembeli }\end{array}$ \\
\hline $\begin{array}{l}\text { Mengetahui } \\
\text { peranan pelaku } \\
\text { rantai pasok } \\
\text { beras di } \\
\text { Kecamatan } \\
\text { Bansari }\end{array}$ & Primer & Wawancara & $\begin{array}{l}\text { Pertanyaan untuk } \\
\text { mendapatkan data } \\
\text { yang digunakan } \\
\text { untuk Analisis } \\
\text { kualitatif }\end{array}$ & $\begin{array}{l}\text { Petani, } \\
\text { penggilingan, } \\
\text { pedagang dan } \\
\text { pembeli }\end{array}$ \\
\hline
\end{tabular}

\section{HASIL DAN PEMBAHASAN}

\section{Pola Mekanisme Rantai Pasok Beras Di Kecamatan Bansari}

Kecamatan Bansari merupakan salah satu kecamatan yang terletak di Kabupaten Temanggung. Sebagian besar masyarakatnya memiliki mata pencaharian sebagai petani, pedagang, tukang bangunan dan karyawan industri. Jagung dan Padi merupakan salah komoditas yang menjadi andalan bagi masyarakat Kecamatan Bansari. Tanaman Padi di Kecamatan Bansari memiliki luas panen $665 \mathrm{Ha}$ dengan produksi 4.445 ton. Setiap tahun petani padi di Kecamatan Bansari hanya melewati satu kali masa panen dengan waktu tanam selama empat bulan. Model pola atau mekanisme aliran rantai pasok beras di Kecamatan Bansari Kabupaten Temanggung secara umum dimulai dari petani, penggilingan, pedagang dan konsumen beras.

Hasil wawancara dengan petani, penggilingan, pedagang dan konsumen mengenai seputar dinamika rantai pasok beras di Kecamatan Bansari dapat dilihat pada pembahasan penelitian ini. Rantai pasok beras pertama di Kecamatan Bansari dimulai dari petani. Petani Padi merupakan produsen yang melakukan aktivitas budidaya Padi, mulai dari persiapan lahan hingga panen. Berdasarkan pola rantai pasok beras, petani Padi di Kecamatan Bansari ada yang tidak menjual hasil panennya dan ada yang menjual hasil panennya. Namun sebagian besar petani Padi di Kecamatan Bansari menjual hasil panennya. Petani yang tidak menjual hasil panennya menggunakan hasil panennya untuk konsumsi sendiri. Sedangkan petani yang menjual hasil panennya, untuk mendapatkan uang sebagai sumber penghasilan, mencukupi kebutuhan seharihari, dan membeli benih untuk modal tanam musim berikutnya. Hasil panen 
yang dijual petani berupa gabah kering panen (GKP), gabah kering giling (GKG) dan beras. Hasil panen tersebut dijual kepada pedagang aktif yaitu pedagang yang mendatangi petani, serta pedagang pasif yaitu petani yang mendatangi pedagang. Pedagang aktif dan pasif ini adalah pedagang yang menjual beras di toko beras, pasar dan warung. Selain pedagang, petani juga menjual hasil panen kepada pengepul, penebas dan penggilingan. Aliran rantai pasok pertama ini bisa dilihat dari gambar 1.

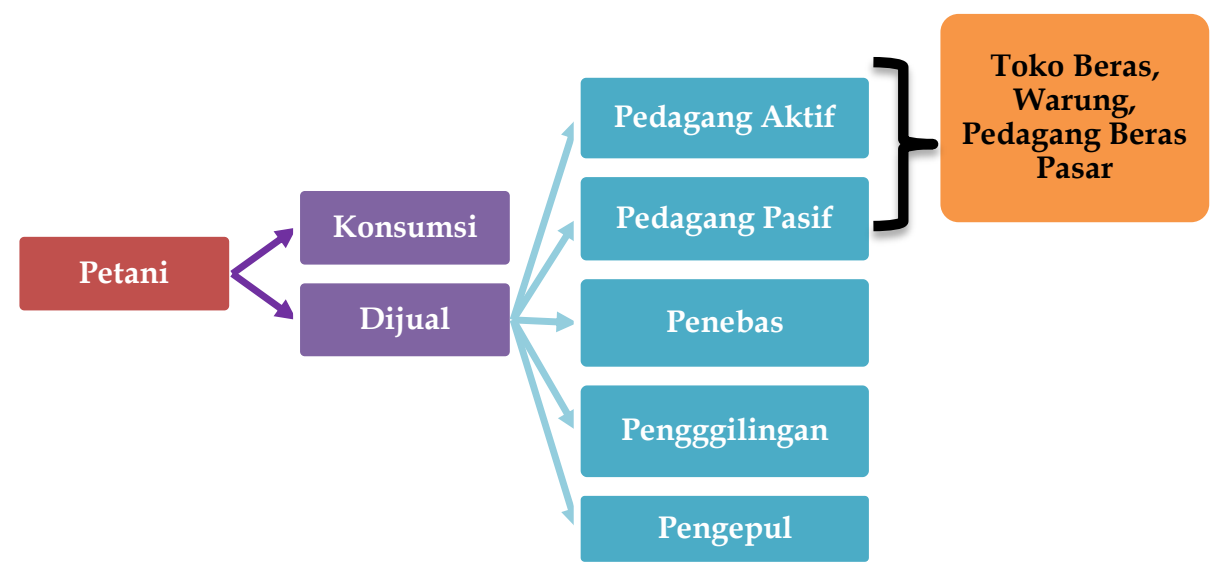

Gambar 1.

Rantai Pasok Pertama (Petani)

Rantai pasok kedua adalah penggilingan. Rantai pasok ditingkat penggilingan bisa dilihat pada gambar 2 .

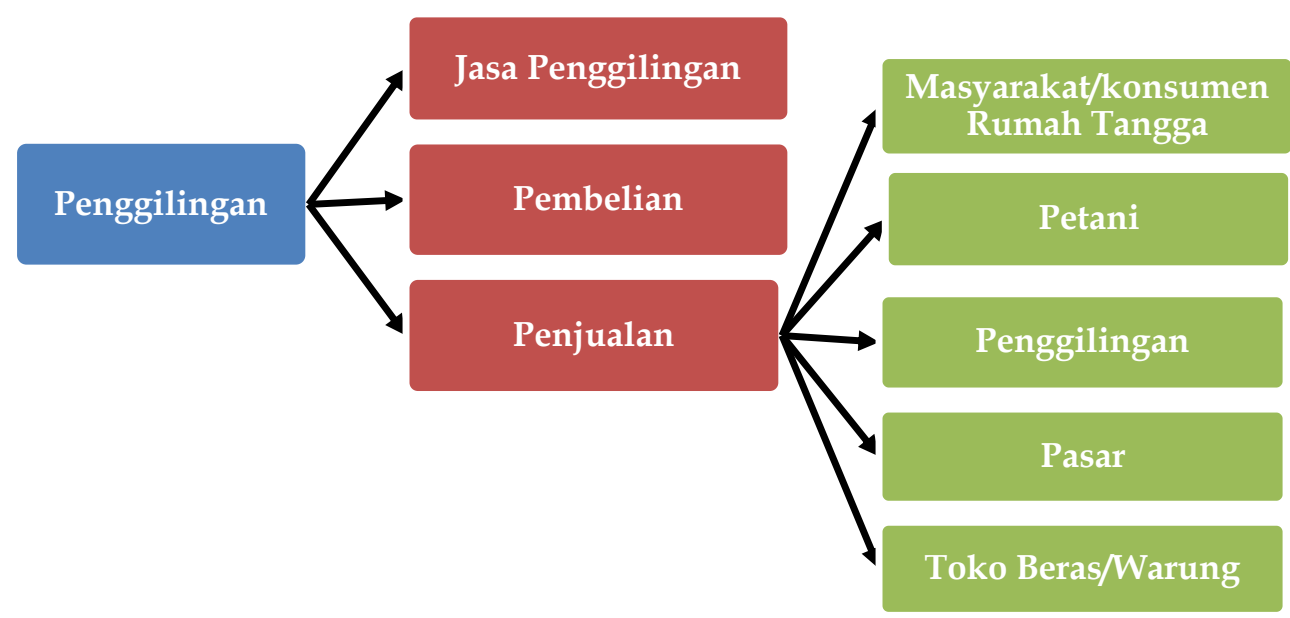

Gambar 2.

Rantai Pasok Kedua (Penggilingan)

366 | Aprillia Palupi, Sony Heru Priyanto; Dinamika Rantai ... 
Penggilingan merupakan kegiatan atau aktivitas menggiling padi menjadi beras. Pada kegiatan rantai penggilingan di Kecamatan Bansari ada yang hanya melakukan jasa penggilingan saja dan adapula yang melakukan kegiatan pembelian dan penjualan. Pada penggilingan yang melakukan jasa penggilingan saja, hanya mengambil upah jasa penggilingan. Sedangkan penggilingan yang melakukan pembelian, pembelian tersebut adalah pembelian gabah dari petani. Sedangkan aktivitas penjualan yang dilakukan pada penggilingan adalah penjualan beras hasil gilingan. Beras hasil gilingan dijual kepada masyarakat atau konsumen rumah tangga, penggilingan, pasar, toko beras dan warung.

Rantai pasok ketiga adalah pedagang beras. Pedagang beras adalah perorangan yang melakukan penjualan beras secara eceran ataupun grosir. Pedagang beras eceran menjual beras dalam jumlah antara $5-20 \mathrm{~kg} /$ hari. Sedangkan pedagang grosir menjual beras antara 3 - $5 \mathrm{kwintal} / \mathrm{hari}$, namun pada pedagang beras grosir juga menyatakan penjualan ditingkat grosir tidak menentu dikarenakan tergantung stock pasokan dari petani. Pada saat musim panen penjualan sedikit, pada musim tidak panen penjualan banyak.

Penjualan beras oleh pedagang dilakukan secara langsung ataupun tidak langsung. Yang dimaksud penjualan secara langsung, pedagang melakukan penjualan kepada konsumen dalam bentuk beras apa adanya tanpa melakukan pengolahan terlebih dahulu. Sedangkan penjualan tidak langsung pedagang melakukan aktivitas lain yaitu pengolahan dengan cara penyortiran memilah antara kualitas yang bagus dan jelek.

Pedagang beras menjual beras kepada konsumen yaitu konsumen rumah tangga dan pedagang berikutnya. Penjualan kepada konsumen rumah tangga dilakukan pedagang dengan menjual beras di warung atau toko milik sendiri. Sedangkan penjualan kepada pedagang lainnya pedagang menjual beras dengan menyetok kepasar. Rantai pasok ketiga dapat lihat pada Gambar 3.

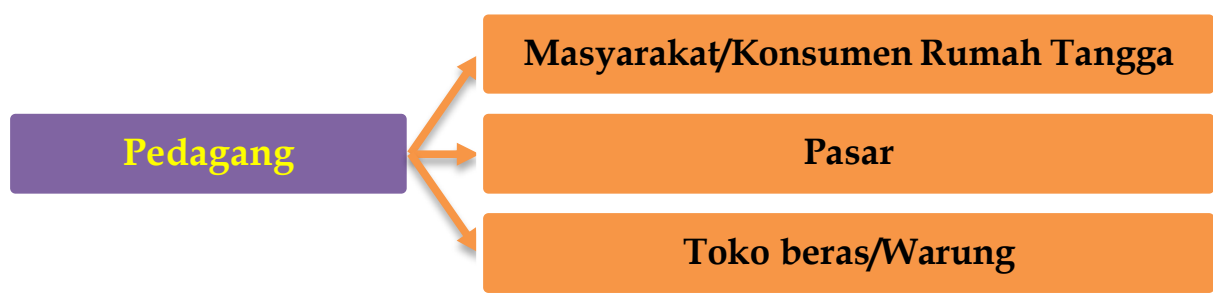

Gambar 3.

Rantai Pasok Ketiga (Pedagang)

Rantai pasok keempat adalah konsumen beras. Konsumen beras di Kecamatan Bansari adalah rumah tangga yang mengkonsumsi beras sebagai bahan pangan. Konsumen beras mendapatkan beras dari warung, pengepul dan 
pedagang desa. Konsumen memilih beras dengan kisaran harga Rp 8.000 - Rp 12.000. Alasan pemilihan harga beras dikisaran tersebut adalah harga murah dan terjangkau, kualitas sedang atau lumayan, dan adanya subsidi dari pemerintah.

Panjang pendeknya mekanisme rantai pasok menentukan efektifitas dan efisiensi dalam pemasaran komoditas beras. Dibandingkan dengan tempat lain seperti di Indramayu yang memiliki mekanisme rantai pasok panjang dan rumit dimulai dari petani, kelompok tani, koperasi, tengkulak, pengepul, Rice Milling Unit (RMU), pasar beras daerah, pengecer dan BULOG. Mekanisme rantai pasok panjang dan rumit menimbulkan tidak tertatanya perdagangan dan harga tinggi di tingkat konsumen (Hidayat, Y.R. 2016). Berdasarkan mekanisme tersebut rantai pasok beras yang ada di Kecamatan Bansari termasuk dalam mekanisme sederhana dan pendek karena aliran produk pada rantai pasok beras dimulai dari petani menjual hasil panennya kepada penebas, pengepul, penggilingan, pedagang aktif, dan pedagang pasif. Dengan mekanisme yang pendek dan sederhana meudahkan untuk menata perdagangan dan mengontrol harga ditingkat konsumen.

\section{Peranan pelaku rantai pasok beras di Kecamatan Bansari}

Merujuk pada pola atau mekanisme rantai pasok beras di Kecamatan Bansari, terdapat beberapa pelaku yang terlibat dalam rantai pasok beras diantaranya petani, pedagang aktif dan pedagang pasif, pengepul, penebas, penggilingan, konsumen rumah tangga. Pelaku rantai pasok ini memiliki peran masing masing dalam mendistribusikan beras dari petani hingga konsumen rumah tangga melalui aktifitas yang dilakukannya. Untuk melihat peranan yang dilakukan setiap pelaku rantai pasok beras di Kecamatan Bansari dapat dilihat dari tabel 2 dibawah ini.

Tabel 2. Peranan Pelaku Rantai Pasok

\begin{tabular}{ll}
\hline \multicolumn{1}{c}{ Pelaku rantai pasok } & \multicolumn{1}{c}{ Peranan dalam rantai pasok } \\
\hline Petani & Menghasilkan gabah/beras, menjual gabah/beras, membeli beras \\
Pengepul & Membeli gabah / beras \\
Penebas & Membeli gabah masih di pohon \\
Penggilingan & Membeli gabah, menggiling gabah menjadi beras, menjual beras \\
Pedagang aktif & Membeli beras, menjual beras \\
Pedagang pasif & Membeli beras, menjual beras \\
Konsumen rumah tangga & Membeli beras \\
\hline
\end{tabular}

Sumber : Data primer penelitian

Peranan pelaku rantai pasok yang pertama yaitu petani. Petani melakukan aktivitas memproduksi beras. Secara umum petani hanya sebagai produsen gabah/beras, namun ada beberapa petani yang melakukan penjualan gabah/beras, serta melakukan pembelian beras. Petani yang hanya 
memproduksi gabah, menggunakan kembali sebagian gabah untuk menanam lagi, dan sisanya untuk konsumsi keluarga. Petani yang menjual gabah/beras bertujuan mendapatkan penghasilan, memperoleh keuntungan yang lebih besar, menukar beras menjadi uang, untuk menghitung untung rugi dari proses produksi yang dilakukan. Karakteristik petani di Kecamatan Bansari terlihat dari tabel 3 di bawah ini.

Tabel 3. Karakteristik Petani Padi di Kecamatan Bansari

\begin{tabular}{ll}
\hline \multicolumn{1}{c}{ Uraian } & \multicolumn{1}{c}{ Keterangan } \\
\hline Usia & $37-65$ tahun \\
Kisaran luas lahan & $250-1000 \mathrm{~m}^{2}$ \\
Pola tanam & Larik, sebar, jajar legowo \\
Pupuk yang digunakan & Urea, NPK, pupuk kandang \\
Varietas ditanam & Sembada, ciliwung, batang gadis, IR68, \\
Hasil panen & Beras merah \\
Bentuk penjualan & $15-30$ karung gabah \\
& Gabah kering panen (GKP), Gabah kering \\
Waktu penjualan & giling (GKG) \\
Sistem pembayaran & 1 minggu setelah panen \\
Intensitas panen & Tunai (timbang bayar) \\
Waktu tanam & 1 kali \\
\hline
\end{tabular}

Sumber : Data primer penelitian

Berdasarkan tabel di atas kisaran usia petani padi di Kecamatan Bansari antara 37- 65 tahun. Dengan rata rata kepemilikan lahan sekitar 250 - 1000 m2. Kepemilikan lahan dengan kisaran luas tersebut petani di Kecamatan Bansari tersebut tergolong sempit (Susilowati dan Maulana, 2012), sehingga termasuk dalam kategori tidak ekonomis untuk usaha tani padi (Ariwibowo, 2013). Pada umumnya, petani padi di Kecamatan Bansari menanam padi hanya satu kali dalam setahun serta menggunakan varietas Sembada meskipun ada pula yang menanam varietas Ciliwung, Batang gadis, IR 68 dan Beras merah. Pola tanam padi dilakukan dengan pola tanam larik, sebar dan jajar legowo. Pupuk yang digunakan untuk tanaman padi, petani banyak memakai pupuk Urea, NPK dan pupuk kandang. Hasil panen yang didapat pada satu kali musim tanam yaitu berkisar 15 - 30 karung gabah. Sehingga mayoritas petani menjual beras dalam bentuk gabah kering (GKG), dengan waktu penjualan 1 minggu setelah panen. Sistem pembayaran yang diterima petani dari hasil penjualan diterima secara tunai atau timbang bayar. Petani padi di Kecamatan Bansari menghadapi masalah dalam penjualan beras yaitu harga yang rendah, harga tidak stabil, banyaknya pesaing, pembeli tidak serius, hasil panen yang tidak sesuai harapan yaitu gabah tidak bernas, serta cuaca pada saat pengeringan gabah tidak mendukung, karena mendung ataupun turun hujan. 
Peranan pengepul secara umum yaitu pihak yang membeli gabah atau beras dari petani produsen. Pengepul menjalankan bisnisnya dengan cara membeli langsung gabah kering panen (GKP), gabah kering giling (GKG) atau padi dari petani setelah selesai memanen. Di Kecamatan Bansari, pengepul menentukan harga beli sangat rendah kepada petani, harga tersebut ditentukan oleh pengepul itu sendiri.

Peranan penebas secara umum hampir sama dengan pengepul. Penebas membeli gabah kering panen (GKP) dari petani pada saat gabah masih ada di pohon dan belum dipanen. Penebas menentukan harga beli kepada petani dengan tafsiran panen dari penebas itu sendiri.

Peranan penggilingan yaitu memproduksi beras melalui proses penggilingan gabah, serta melakukan penjualan. Penggilingan mendapatkan gabah untuk digiling yaitu dari kegitan menanam sendiri tanaman padi dan melakukan pembelian gabah dari petani kemudian digiling menjadi beras. Penggilingan menjalankan usahanya untuk kebutuhan masyarakat sekitar yaitu dengan tujuan membantu konsumen atau petani pada jasa penggilingan, serta membantu konsumen dalam penyediaan beras. Karakteristik penggilingan padi di Kecamatan Bansari terlihat pada tabel 4 dibawah ini

Tabel 4. Karakteristik Penggilingan Padi di Kecamatan Bansari

\begin{tabular}{ll}
\hline \multicolumn{1}{c}{ Uraian } & \multicolumn{1}{c}{ Keterangan } \\
\hline Usia pengusaha penggilingan & $28-45$ tahun \\
Kapasitas mesin & $24 \mathrm{pk}$ \\
Jumlah gabah giling & $1 \mathrm{kwintal}-10$ ton / hari \\
Upah penggilingan & $500 / \mathrm{kg}$ gabah kering giling \\
Harga beli gabah & Rp 4.300 - Rp 7.000 \\
Varietas & Sembada, Ciherang, Mentik wangi, \\
Harga jual beras & Rp 9.500 - Rp 12.000 \\
Sistem penjualan beras selep & Bertahap \\
Sistem pembayaran & Tunai, transfer \\
\hline
\end{tabular}

Sumber : Data primer penelitian

Pelaku penggilingan di Kecamatan Bansari memiliki usia 28 - 45 tahun, usia tersebut lebih produktif dibandingkan rentang usia petani. Penggilingan beras di Kecamatan Bansari rata-rata memiliki kapasitas mesin yang hampir sama yaitu 24 pk, dengan jumlah yang digiling 1 kwintal - 10 ton gabah kering giling per hari. Upah penggilingan dalam setiap $1 \mathrm{~kg}$ gabah kering giling sebear Rp 500. Penggilingan membeli gabah dengan harga Rp 4.300 - Rp 7.000 dengan varietas yang paling dominan adalah varietas sembada, Ciherang dan Mentik Wangi. Gabah yang digiling pada akhirnya dijual dalam bentuk beras dengan kisaran harga Rp 9.500 - Rp 12.000. Sistem penjualan beras dilakukan secara bertahap. Penjualan bertahap tersebut dilakukan untuk mendapatkan 
keuntungan dikarenakan harga beras yang tidak menentu. Sistem pembayaran yang dilakukan dengan menggunakan uang tunai dan transfer.

Pedagang beras berperan membeli gabah kering panen (GKP) dan menjual beras. Pedagang beras yang membeli gabah kering panen (GKP) dari petani melakukan penjemuran dan penyelepan gabah kering giling (GKG) di penggilingan, kemudian menjualnya menjadi beras. Namun kebanyakan pedagang beras di Kecamatan Bansari merupakan pedagang yang menjual beras secara langsung, hanya sedikit yang melakukan penyortiran untuk memisahkan antara beras dengan kualitas jelek dan kualitas bagus. Karakteristik pedagang beras di Kecamatan Bansari terlihat dari tabel 5 dibawah ini.

Tabel 5. Karakteristik Pedagang Beras di Kecamatan Bansari

\begin{tabular}{ll}
\hline \multicolumn{1}{c}{ Uraian } & \multicolumn{1}{c}{ Keterangan } \\
\hline Kategori pedagang & Eceran dan grosir \\
Jumlah penjualan & $5 \mathrm{~kg} /$ hari $-5 \mathrm{kwintal} / \mathrm{hari}$ \\
Harga beras & $\mathrm{Rp} 8.000-\mathrm{Rp} 12.000$ \\
Jenis beras yang dijual & Sembada, ciliwung, IR 68, rajalele, beras \\
& kantil, beras ketan, beras merah \\
Bentuk penjualan & Dijual langsung tanpa pengolahan \\
System pembayaran & Tunai (timbang bayar), hutang, transfer \\
Tempat penjualan & Warung, pasar \\
Waktu penjualan & Setiap hari \\
\hline
\end{tabular}

Sumber : Data primer penelitian

Pedagang beras di Kecamatan bansari termasuk dalam kategori pedagang eceran dan grosir. Pedagang beras melakukan penjualan berkisar $5 \mathrm{~kg} /$ hari - 5 kwintal/hari. Harga beras yang dijual berkisar Rp 8.000 - Rp 12.000. Harga beras di pedagang grosir lebih murah dibanding harga beras di pedagang eceran. Untuk jenis varietas beras yang dijual adalah varietas Sembada, ciliwung, IR 68, rajalele, beras kantil, beras ketan, beras merah. Beras sembada merupakan beras dengan harga paling murah. Beras yang dijual oleh pedagang hanya dilakukan pengolahan sederhana tanpa perlakuan pengemasan, yaitu dengan penyortiran memisahkan antara kualitas yang bagus dan yang jelek. Tempat penjualan beras dilakukan di warung dan dipasar, dengan waktu penjualan setiap hari. Sistem pembayaran dilakukan secara tunai (timbang bayar), transfer namun ada pula yang di hutang.

Pembeli beras di Kecamatan bansari berperan sebagai konsumen akhir yaitu konsumen rumah tangga. Karakteristik konsumen beras dapat dilihat dari tabel 6. Konsumen rumah tangga membeli beras tergantung kebutuhan yaitu antara $10-50 \mathrm{~kg}$ / bulan. Kisaran harga beras yang dibeli antara Rp. 8.000 - Rp 12.000. Alasan membeli beras dengan harga tersebut dikarenakan harganya murah dan terjangkau, mendapat subsidi dari pemerintah, kualitas lumayan bagus atau sedang. Varietas beras yang banyak dibeli adalah varietas sembada, 
raja lele, menthik wangi, ciherang, local, beras merah dn khantil. Konsumen rumah tangga tersebut membeli beras secara tunai di warung atau pedagang di desa, pasar dan pengepul. Konsumen membeli beras jika butuh dan stok beras dirumah akan habis. Konsumen beras menghadapi kendala pada saat pembelian beras yaitu kelangkaan varietas yang diinginkan, harganya tidak pasti, beragamnya varietas menyebabkan konsumen bingung memilih. Tujuan pembelian beras digunakan untuk dikonsumsi sendiri dan simpan sebagai stok rumah tangga.

Tabel 6. Karakteristik Konsumen Beras di Kecamatan Bansari

\begin{tabular}{ll}
\hline \multicolumn{1}{c}{ Uraian } & \multicolumn{1}{c}{ Keterangan } \\
\hline Jumlah pembelian & $10-50 \mathrm{~kg} /$ bulan \\
Harga & Rp 8.000 - Rp 12.000 \\
Jenis beras & Sembada, raja lele, menthik wangi, ciherang, \\
Tempat membeli & local, beras merah, kanthil \\
System pembayaran & Warung, pasar, pedagang desa, pengepul \\
Tujuan pembelian & Tunai \\
\hline
\end{tabular}

Sumber : Data primer penelitian

Secara umum terdapat banyak lembaga atau komponen pelaku pada rantai pasok beras. Setiap lembaga atau komponen tersebut memiliki peran yang berbeda-beda. Pada rantai pasok beras di Indramayu Rice Milling Unit (RMU) memiliki peranan dan pengaruh besar terhadap pemasaran beras, dikarenakan menghasilkan, membeli, menjual dan mendistribusikan. Sedangkan peranan pelaku pada rantai pada rantai pasok beras di Kecamatan Bansari yang paling berperan adalah petani karena petani menghasilkan, menjual, membeli, konumsi dan mendistribusikan. Sedangkan peranan pelaku rantai pasok selain petani hanya membeli, menjual dan mendistribusikan.

\section{SIMPULAN DAN SARAN}

\section{Simpulan}

Perancangan desain pola rantai pasok merupakan satu kegiatan strategis yang harus dilakukan pada supply chain management yang mencakup keputusan tentang lokasi, jumlah, dan kapasitas fasilitas produksi dan distribusi dalam suatu rantai pasok (Pujawan dan Mahendrawati. 2010). Dari pola mekanisme pelaku rantai pasok beras yang ada di Kecamatan Bansari, hanya memiliki satu aliran rantai pasok yaitu aliran produk. Pola atau mekanisme rantai pasok tersebut menjelaskan mengenai pihak-pihak yang terlibat pada rantai pasok Beras di Kecamatan Bansari. Aliran produk pada rantai pasok beras 
terdiri dari aliran rantai pasok beras dan aliran rantai pasok gabah. Pada rantai pasok beras di Kecamatan Bansari, pola rantai tersebut merupakan gambaran dari stock and flow. Petani menjual hasil panennya kepada penebas, pengepul, penggilingan, pedagang aktif, dan pedagang pasif. Petani menjual hasil panen berupa gabah kepada penebas, pengepul, penggilingan, pedagang aktif dan pedagang pasif, namun pada pedagang pasif petani juga menjual gabah yang sudah diselep yaitu berupa beras.

\section{Saran}

Berdasarkan hasil penelitian mengenai Dinamika Rantai Pasok Beras di Kecamatan Bansari, ada beberapa saran yang dapat dijadikan bahan pertimbangan atau masukan agar pola mekanisme dan peranan pelaku rantai pasok di Kecamatan Bansari bisa lebih efektif dan efisien diantaranya adalah perlu pengembangan pola rantai pasok selain rantai pasok produk. Perlu adanya campur tangan pemerintah untuk mengontrol dan membantu dalam regulasi rantai pasok beras di Kecamatan Bansari. Serta diperlukannya kemitraan bisnis untuk mengembangkan usaha dalam kegiatan rantai pasok beras di Kecamatan Bansari agar semua pelaku memperoleh keuntungan.

\section{DAFTAR PUSTAKA}

Ariwibowo, A. 2013. Analisis Rantai Distribusi Komoditas Padi dan Beras di Kecamatan Pati Kabupaten Pati. Economics Development Analysis Journal, 2(2): 1-9.

Bantacut, T., dan Fadhil, R. 2018. Penerapan Logistic 4.0 dalam Manajemen Rantai Pasok Beras Perum Bulog : Sebuah gagasan. Jurnal Pangan, 27(2): 141-154.

Ghozali, M.I. 2016. Rantai Pasok Beras pada Bulog Berbasis Neural Network. Jurnal Simetris, 7(2): 743-752.

Hidayat, Y.R. 2016. Analisis Stakeholders Rantai Pasok Beras di Kabupaten Indramayu. Jurnal Logika, 18(3): 54-60.

Kusumaningrum, R., Harianto., dan Sinaga, B.M. (2010). Dampak kebijakan harga pasar pembelian pemerintah terhadap penawaran dan permintaan beras di Indonesia. Jurnal Forum Pasca Sarjana, 33(4): 229 - 238.

Luas panen, produksi dan produktivitas padi sawah menurut Kabupaten/Kota di Jawa Tengah tahun 2018, diakses 8 Juli 2019 dikutip dari https://jateng.bps.go.id/dynamictable/2016/12/19/44/luas-panenproduksi-dan-produktivitas-padi-provinsi-jawa-tengah-menurutkabupaten-kota-2018.html

Mahbubi, A. 2013. Model Dinamis Supply Chain Beras Berkelanjutan dalam Upaya Ketahanan Pangan Nasional. Jurnal Manajemen dan Agiribisnis 
10(2): 81-89.

Milled Rice Production by Country in 1000 MT, diakses 10 Agustus 2019, dikutip dari https://www.indexmundi.com/agriculture/?commodity= milledrice\&graph=production

Muhandhis, I., dan Suryani, I. 2015. Pengembangan Model Rantai Pasok Produksi Beras Untuk Meningkatkan Ketahanan Pangan dengan Menggunakan Sistem Dinamik. Prosiding Seminar Nasional Manajemen Teknologi XXIII.

Muhdiar, A.S., dan Halimah. 2018. Analisis Margin Pemasaran Beras Kecamatan Sibulue Kecamatan Bone. Jurnal Pendidikan Teknologi Pertanian, 4: 79-86.

Nahumury, M.A.I., dan Widiastuti, M.M.D. 2015. Kajian Rantai Pasok Beras di

Distrik Tanah Miring Kabupaten Merauke. Jurnal Agricola, 5(1): 32-46.

Pujawan, I.N., dan Mahendrawathi, E.R. (2010). Supply Chain Management. Edisi Kedua. Guna Widya. Surabaya.

Rice consumption worldwide in 2018/2019, by country (in 1,000 metric tons)*, diakses 2 Januari 2020 dikutip dari https://www.statista.com/statistics/255971/top-countries-based-onrice-consumption-2012-2013/

Salsabilla,S.M., Wibowo, R., dan Agustina, T. 2014. Analisis Manajemen Rantai Pasok (Supply Chain Management) Padi Pasca Panen di Pabrik Beras Sukoreno Makmur Kecamatan Kalisat. Jurnal Berkala Ilmiah Pertanian, 10(10): 1-12.

Saragih, A.E., Tinaprilla, N., dan Rifin, A. 2017. Rantai Pasok Produk Beras di Kecamatan Cibeber Kabupaten Cianjur. Jurnal Manajemen dan Agribisnis, 14(3): 218-229.

Sugiyono. 2008. Metode penelitian kuantitatif, kualitatif dan R\&D. Alfabeta. Bandung.

Suoth, I., Sumarau, J., dan Karuntu, M. 2017. Analisis Desain Jaringan Supply Chain komoditas beras di Desa Karondoran Kecamatan Langowan timur Kabupaten Minahasa. Jurnal Ekonomi Manajemen Bisnia Akutansi, 2(2): 511519.

Suryana, A., dan Mardianto, S. 2001. Bunga Rampai Ekonomi Beras. Lembaga pendidikan ekonomi dan masyarakat Fakultas Ekonomi Universitas Indonesia. Jakarta.

Susilowati, S.H., dan Maulana, M. 2012. Luas Lahan Usaha Tani dan Kesejahteraan petani "Eksistensi Petani Gurem dan Urgensi Kebijakan Reforma Agraria". Jurnal Analisis Kebijakan Pertanian, 10(1): 17-30.

Trisilawaty, C., Marimin., dan Achsani, N.A. 2011. Analisis Optimasi Rantai Pasok Beras dan Penggunaan Gudang di Perum Bulog Divre DKI Jakarta. Jurnal Pangan, 20(2): 177-195.

Yanuarti, A.R., dan Afsari, M.D. 2016. Profil komoditas barang kebutuhan pokok dan barang penting komoditas Beras. Kemendag. Jakarta. 